já paga, à gente toda que emprega e destacando por fim a sorte de o país ter cidadãos comprometidos com o trabalho e o progresso como ele, o que o dispensava totalmente de "caridades duvidosas". Mas tão rápido como esse pensamento um homem que se rastejava pela calçada se aproximou e o agarrou pela barra da calça pedindo dramaticamente por uma moeda. "Senhor?!", interpelava a moça de um lado; "só cinquenta centavos", apelava o pedinte do outro. Atormentado e já manifestando os tais sintomas, ele se retirou com certo ímpeto e sem dizer uma palavra, deixando "aquela gente impertinente" a se importunar e se ressentir mutuamente, quando, na pressa de sair dali e chegar logo ao trabalho, pisou em falso em um buraco na calçada, caindo de cara no chão.

Não há quem não tenha sofrido ou visto um tombo na vida, mas como não se cai nunca do mesmo jeito e como uma queda não é apenas cômica por si só, mas parece reavivar as graças de todas as outras, cair é sempre fazer rir. E assim Pedro, que se recusava à caridade, deu a muita gente motivos pra gargalhar, chocalhar e esquecer por um instante suas misérias. A compaixão chegou mais tarde, combalida das pernas pelo espasmo cômico, de nervos relaxados, e atrapalhada. "O senhor tá bem?"; "se machucou?!" Ao que ele respondia com resmungos e um discreto balançar afirmativo de cabeça. Aliviadas de si, as consciências em volta deram livre passagem ao cartorário, cujos membros já sambavam involuntariamente, e às gargalhadas, com a impressão de que o dia começava bem.

Praguejando, maldizendo o buraco, a cidade, o país e invocando "o diabo que os carregue", Pedro seguiu rumo ao seu cartório, onde já notavam sua ausência. "Será que ele tá doente ou... morreu?!" perguntava uma recepcionista, lembrando-se que nunca soube de um atraso seu em muitos anos na firma. "Ih, vazo ruim, minha filha...", respondeu outra, certa de que o "velho" não tardava a chegar; e chegou, esbaforido, desalinhado e intragável. "Liga pra" fulano, "chama" sicrano, ordenava, em tom imperativo.

Foi a custo, mas não sem um certo prazer, que as moças comunicaram a seu patrão que fulano, sicrano e ainda beltrano não se encontravam e que não voltariam tão cedo, pois aderiam à grave municipal deixando um comunicado oficial expedido pelo sindicato.

Pedro era só tremores.

\section{treinamento para habilitados}

\section{Maria Scarte $^{1}$}

O poeta escreveu um livro sobre a cidade

Vila Maria Vila Maria

Só seus contornos que me sobraram

Só a terra debaixo do asfalto

Testemunharam a cidade grande mas provinciana

Quisera ver o que viam nos anos vinte

Nos cinquenta e nos sessenta

Mas a memória das pessoas daqui não chega nos detalhes mórbidos

Na paisagem fixa em constante mudança

No tempo bruto e sem semelhança

Vila Maria Vila Maria

Vila Maria Vila Mariana

As voltas que seu corpo faz

Só transportam o olhar sagaz

De quem constrói e não se satisfaz

De quem vive e não acha paz

Sempre trabalha querendo mais

Vila Maria Vila Maria

Qual é o encanto que esse chão tem

Qual é o frescor dessa polvição

Qual é o rio que não é Tietê

Que bateria é essa no meu coração

1 E-mail para contato: mscarte@outlook.com. 